\section{PEER-REVIEWED ARTICLE}

Food Protection Trends, Vol 41, No. 3, p. 314-322 Copyright ${ }^{\circledR}$ 2021, International Association for Food Protection 2900 100th Street, Suite 309, Des Moines, IA 50322-3855
Alexander W. Emch, Samantha Burroughs, Javier Gaspar-Hernandez and Joy G. Waite-Cusic*

*Dept. of Food Science and Technology 100 Wiegand Hall, Oregon State University, Corvallis, OR 97331, USA

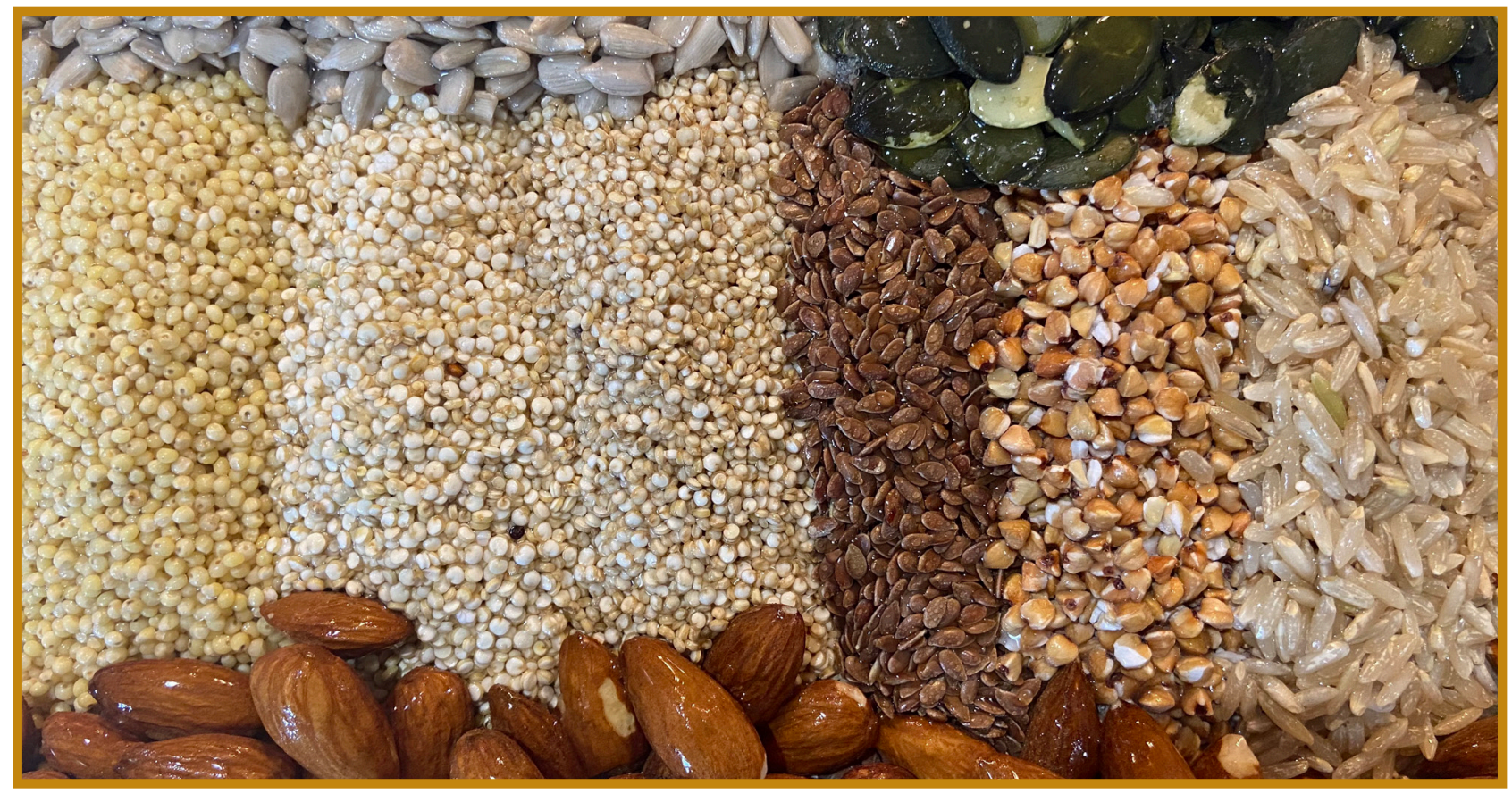

\title{
Salmonella Growth during the Soaking Step of "Sprouted" Grain, Nut, and Seed Production
}

\section{ABSTRAGT}

Food companies are marketing products with "sprouted," "activated," or "awakened" ingredients. The label implies that germination of grains, nuts, and seeds confers improved health benefits; however, the "sprouting" process consists of a simple overnight soak in water often at ambient temperature, followed immediately by drying and further processing. Our objective was to quantify Salmonella growth during soaking of grains, nuts, and seeds commonly included in "sprouted" products. Raw grains (buckwheat, millet, quinoa, rice), nuts (almond, cashew, hazelnut, peanut, pecan, walnut), and seeds (flax, hemp, pumpkin, sunflower] were inoculated with Salmonella to achieve $3 \log \mathrm{CFU} / \mathrm{g}$ after drying. Inoculated samples $[20 \mathrm{~g}$ ] were soaked in water $[20 \mathrm{~mL}$ ] with incubation at 7 or $25^{\circ} \mathrm{C}$ for $24 \mathrm{~h}$. Salmonella bacteria were enumerated using serial dilution and spread plating on Hektoen enteric agar $\left(37^{\circ} \mathrm{C}, 24 \mathrm{~h}\right.$ ). Salmonella was capable of significant growth ( $>3 \log \mathrm{CFU} / \mathrm{g}$ ) in all 15 grains, nuts, and seeds during ambient temperature soaking, reaching an average concentration of $7.05 \log \mathrm{CFU} / \mathrm{g}$. High salt concentrations
( $>10 \%$ ) and refrigeration $\left[<7^{\circ} \mathrm{C}\right.$ ) were verified to prevent growth of Salmonella during soaking. This study demonstrates the risk of ambient temperature "sprouting" practices and presents practical strategies to improve safety of these products.

\section{INTRODUCTION}

The healthy snack market was valued at $\$ 21$ billion globally in 2017 and is projected to grow 5\% annually over the next decade (8). Many established food businesses as well as food entrepreneurs in the Pacific Northwest are marketing new products to target entry into the healthy snack market category. Differentiation in this product category is important to product success in this crowded marketplace. Recent differentiators have included "raw," "gluten-free," "nonGMO,” "sustainably produced," "locally sourced," and "paleofriendly." Grains, nuts, and seeds are significant ingredients in the healthy snack segment due to their high-quality protein and "healthy" fats, along with abundant antioxidant, fiber, and mineral content $(5,17,18)$. New products including grains, nuts, and seeds that are "sprouted," "awakened," and 
"activated" are perceived to provide added value. Companies producing these "sprouted" products simply soak raw ingredients (nuts, seeds, grains, etc.) in water overnight, often at ambient temperature. Soaking softens the hull of the nuts, seeds, or grains and leads to swelling that initiates the activation of enzymes and reduction of antinutrients (e.g., phytic acid), which are marketed as providing health benefits (16). Following soaking, these ingredients are typically dried under low temperature (often $<55^{\circ} \mathrm{C}$ ) and low humidity (< $50 \%$ relative humidity) to their original water activity and are packaged as single-ingredient snacks (e.g., raw, sprouted almonds), incorporated into a complex snack (e.g., granola, bars, trail mix), or pureed into nut or seed butters or as a base for fermented nondairy "cheeses" (personal communication). These "sprouted" products are considered by consumers to be "raw" and "living," and they serve the needs of the general consumer as well as vegan and raw food dieters (13).

Three outbreaks have been linked to the consumption of "sprouted" products, specifically sprouted chia seed powder, cashew nut cheese, and raw sprouted nut butters $(11,12$, 19). In response to the chia powder outbreak, Health Canada and the Canadian Food Inspection Agency conducted an investigation to determine the level of Salmonella contamination in the implicated product (sprouted chia powder) and a co-manufactured product (sprouted flax powder). The finished sprouted chia powder was determined to be contaminated with Salmonella at levels of 7.9 to 17.5 most probable number per $100 \mathrm{~g}$. Many of the ingredients (grains, nuts, and seeds) used in "sprouted" products have been associated with a number of recalls and outbreaks in recent years $(9-11,20,25)$. Further studies on tree nuts have quantified low levels of Salmonella contamination (typically $<20 \mathrm{CFU} / 100 \mathrm{~g})(1,3,4,26)$. Grains, nuts, and seeds do not have sufficient moisture to support the growth of foodborne pathogens; however, the soaking stage of "sprouting" may create an environment that could support the growth of various microorganisms, including Salmonella. A single study conducted by Keller et al. (2018) demonstrated significant growth (>3 log CFU/g) of Salmonella during the 24-h soaking period of pumpkin, sunflower, and chia seeds at $25^{\circ} \mathrm{C}$ (14). These results indicated that growth of Salmonella during the soaking period may have been a significant factor in the chia seed powder outbreak. Beyond this study, there is limited information on whether the hydration of other grains, nuts, and seeds used in the formulation of "sprouted" products would be sufficient for Salmonella replication within the 24-h soaking period.

Significant research has been conducted that demonstrates the growth of Salmonella, Shiga toxin-producing Escherichia coli, and other foodborne pathogens during the production of traditional sprouts (alfalfa, radish, etc.) that are characterized by obvious plant growth (shoots, leaves, etc.). Sprouts production includes multiple stages characterized as storage, rinsing, pregermination soak, rinse, germination and growth, packaging, cooling and storage, and distribution $(15,21)$. This production process spans several days with incubation at high humidity at ideal temperatures 25 to $30^{\circ} \mathrm{C}$ that leads to high total bacterial cell density ( $>7 \log \mathrm{CFU} / \mathrm{g}$ ), which could include high numbers of pathogenic species $(7,22,24)$. The result is a product intended to be directly consumed that has the potential for hosting high cell densities of bacterial pathogens. Although there has been significant research on traditional sprouts, the process and characteristics of the finished "sprouted" product are substantially different to true sprouts and provide little insight on the relative risk of these production steps.

The objective of this study was to demonstrate the potential for Salmonella to grow during the soaking period of various grains, nuts, and seeds commonly used in commercially available "sprouted" products. A secondary objective of this study was to determine the utility of easily implementable and cost-effective controls (i.e., refrigeration or salt addition) to prevent growth of Salmonella during soaking. Demonstration of pathogen growth (or lack thereof) during soaking would provide clear evidence to facilitate hazard analysis and preventive control decisions by the food industry and provide regulators with clear guidance on the risks associated with this new category of "sprouted" products.

\section{MATERIALS AND METHODS}

\section{Bacterial strains and inoculum preparation}

Six Salmonella enterica strains previously associated with tree nut and peanut products were selected for use in the inoculation cocktail (Table 1). Individual strains were transferred from frozen stock $\left(-80^{\circ} \mathrm{C}\right)$ to tryptic soy broth (TSB; Neogen, Lansing, MI) and incubated at $37^{\circ} \mathrm{C}$ for $24 \mathrm{~h}$. Individual strains were confirmed to be Salmonella by displaying typical morphology on Hektoen enteric agar (Neogen) following incubation at $37^{\circ} \mathrm{C}$ for 24 to $48 \mathrm{~h}$. Isolated colonies were transferred from Hektoen enteric agar to fresh TSB and cultured as described above. Aliquots (100 $\mu \mathrm{L})$ of TSB culture were spread plated onto tryptic soy agar (TSA; Neogen) and incubated at $37^{\circ} \mathrm{C}$ for $24 \mathrm{~h}$ to produce a bacterial lawn. Bacterial lawns were harvested with $5 \mathrm{~mL}$ of $0.1 \%$ peptone water (Neogen) using a sterile cell spreader. Immediately following harvest, individual strains were mixed in equal volume in a $50-\mathrm{mL}$ conical tube to create a Salmonella cocktail. The cocktail was diluted in $0.1 \%$ peptone water to achieve a cell density of $\sim 5 \log \mathrm{CFU} / \mathrm{mL}$.

\section{Inoculation of grains, nuts, and seeds}

Minimally processed grains (brown rice, buckwheat, millet, quinoa), nuts (almond, cashew, hazelnut, peanut, pecan, pili nut, walnut), and seeds (flax, hemp, pumpkin, sunflower) were supplied by local food companies or purchased from the bulk food section of local grocery stores. Individual nut types $(20 \mathrm{~g})$ were aseptically transferred 


\section{TABLE 1. Salmonella enterica strains included in the inoculation cocktail for soaking}

studies of grains, nuts, and seeds

\begin{tabular}{l|l|l|l}
\hline Salmonella Serotype & Isolate Identifier & Description & Isolate Source \\
\hline Enteritidis PT30 & ATCC BAA-1045 & Almond isolate & $\begin{array}{l}\text { American Type } \\
\text { Culture Collection }\end{array}$ \\
\hline Enteritidis PT9c & RM4635 & $\begin{array}{l}\text { Clinical isolate from almond } \\
\text { outbreak }\end{array}$ & $\begin{array}{l}\text { Rob Mandrell } \\
\text { USDA-ARS }\end{array}$ \\
\hline Montevideo & GRC1 & Pistachio isolate & Food and Drug Administration \\
\hline Paratyphi B var. L (+)tartrate(+) & OSPHL 15092808070 & $\begin{array}{l}\text { Clinical isolate from 2015 } \\
\text { outbreak associated with raw } \\
\text { sprouted nut butters }\end{array}$ & $\begin{array}{l}\text { Oregon State Public } \\
\text { Health Labs }\end{array}$ \\
\hline Oranienburg & MDD317 & Pecan isolate & $\begin{array}{l}\text { Michelle Danyluk } \\
\text { University of Florida }\end{array}$ \\
\hline Tennessee & MDD319 & $\begin{array}{l}\text { Clinical isolate from peanut } \\
\text { butter outbreak }\end{array}$ & $\begin{array}{l}\text { Larry Beuchat } \\
\text { University of Georgia }\end{array}$ \\
\hline
\end{tabular}

onto sterile weighing boats and mixed with $2 \mathrm{~mL}$ of diluted inoculum with a sterile utensil to coat. For seeds and grains, the inoculum was applied with an atomizer (Specialty Bottle, Seattle, WA) via spraying $1 \mathrm{~mL}$ of diluted inoculum directly onto seed and grain products $(20 \mathrm{~g})$ spread out in weigh boats. After coating or mixing, inoculated product was dried in the biological safety cabinet at ambient temperature for $24 \mathrm{~h}$ to return product to original moisture content. Inoculated product $(\sim 3 \log \mathrm{CFU} / \mathrm{g})$ was used immediately for experimentation after the drying period.

\section{Soaking process}

Inoculated product was mixed and aliquoted $(20 \mathrm{~g})$ into sterile $50-\mathrm{mL}$ conical bottom tubes. Sterile distilled water $(20$ $\mathrm{mL} ; \mathrm{pH} 6.44)$ was added to each tube and incubated at $22^{\circ} \mathrm{C}$ for $24 \mathrm{~h}$. Additionally, almond samples were soaked in salt solutions at various concentrations $(1.5,10,20 \%)$ for $24 \mathrm{~h}$. Uninoculated controls were prepared in the same manner to evaluate changes in the cell density of natural microbiota, $\mathrm{pH}$, water activity, and moisture content.

\section{Microbial analyses}

Upon completion of a 24-h soak, the hydrated product and soaking solution were mixed thoroughly by shaking the conical tubes for $30 \mathrm{~s}$. For products that thickened during soaking (i.e., flax and hemp), the entire sample (product and solution) was homogenized with an equal volume (1:1) of $0.1 \%$ peptone water. Soaking solution was aseptically transferred and serially diluted in $0.1 \%$ peptone water, and appropriate dilutions were spread plated on Hektoen enteric agar (inoculated samples) or TSA (uninoculated samples).
Inoculated, unsoaked samples were mixed with $20 \mathrm{~mL}$ of $0.1 \%$ peptone water, mixed, serially diluted, and plated as described for soaked samples. Plates were incubated at $37^{\circ} \mathrm{C}$ for 24 to $48 \mathrm{~h}$ prior to enumeration.

\section{$\mathrm{pH}$, water activity, and moisture content}

Samples were tested for water activity with the AquaLab CX-2 or 4TE water activity benchtop meter (Decagon Devices, Inc., Pullman, WA). Moisture content was measured with the HB43-S halogen moisture analyzer using method 1530.08 (Mettler Toledo, Columbus, OH). Product samples were finely chopped in a food processor prior to moisture content and water activity analyses. The $\mathrm{pH}$ of water, soaking solution, and product were measured with the SympHony H10P pH meter (VWR, Radnor, PA) or the Apera SX811SS (Apera Instruments, Columbus, $\mathrm{OH}$ ). Prior to $\mathrm{pH}$ measurement, distilled water was added to product samples (1:1) and blended to homogenize.

\section{Statistical analysis}

Biological replication at the cocktail preparation level was performed in triplicate, and Salmonella growth experiments for each product were performed in triplicate for each biological replicate $(n=9)$. Natural microbiota growth experiments were performed on uninoculated products on 2 days in triplicate $(n=6)$. Moisture content, water activity, and $\mathrm{pH}$ of uninoculated unsoaked and soaked products were measured on one sample per product per day $(n=2)$. Mixed model and one-way analysis of variance with a Tukey's test as the post hoc analysis were performed to determine the impact of water activity, moisture content, $\mathrm{pH}$, and initial 
TABLE 2. Moisture content, water activity, and pH of grains, nuts, and seeds before and after soaking in water at $22^{\circ} \mathrm{C}$ for $24 \mathrm{hrs}$. Values are expressed as the mean \pm standard error $(n=2)$. Within each column, means with different capital letters are significantly different $(P<0.05)$. Columns with no capital letters indicate that there was no significant difference in that variable as a function of product type. Within each row, means with different lowercase letters are significantly different $(\boldsymbol{P}<\mathbf{0 . 0 5}$ ) for a given variable (moisture content, water activity, pH] for initial and soaked product

\begin{tabular}{|c|c|c|c|c|c|c|c|c|}
\hline \multirow{2}{*}{\multicolumn{2}{|c|}{ Product }} & \multicolumn{2}{|c|}{ Moisture Content (\%) } & \multicolumn{2}{|c|}{ Water Activity $\left(\mathrm{a}_{\mathrm{w}}\right)$} & \multicolumn{3}{|c|}{$\mathrm{pH}$} \\
\hline & & \multirow{2}{*}{$\begin{array}{c}\text { Initial } \\
9.01 \pm \\
0.59^{\mathrm{Ba}}\end{array}$} & \multirow{2}{*}{$\begin{array}{c}\text { After } 24-h r \\
\text { Soak } \\
22.44 \pm \\
1.07^{\mathrm{EFb}}\end{array}$} & \multirow{2}{*}{$\begin{array}{c}\text { Initial } \\
0.501 \pm \\
0.003^{\mathrm{Aa}}\end{array}$} & \multirow{2}{*}{$\begin{array}{c}\begin{array}{c}\text { After } 24-h r \\
\text { Soak }\end{array} \\
0.991 \pm \\
0.004^{\mathrm{b}}\end{array}$} & \multirow{2}{*}{$\begin{array}{c}\text { Initial } \\
6.39 \pm \\
0.03^{\mathrm{DEa}}\end{array}$} & \multirow{2}{*}{$\begin{array}{c}\begin{array}{c}\text { After 24-hr } \\
\text { Soak }\end{array} \\
6.29 \pm \\
0.01^{\mathrm{DEFa}}\end{array}$} & \multirow{2}{*}{$\begin{array}{c}\begin{array}{c}\text { Soaking } \\
\text { Solution }\end{array} \\
\text { So }^{a}\end{array}$} \\
\hline \multirow{4}{*}{ Grains } & Brown Rice & & & & & & & \\
\hline & Buckwheat & $\begin{array}{c}8.41 \pm \\
0.02 \mathrm{~B}^{\mathrm{Ca}}\end{array}$ & $\begin{array}{c}36.51 \pm \\
3.24^{\mathrm{CDEb}}\end{array}$ & $\begin{array}{c}0.359 \pm \\
0.002^{\mathrm{CDa}}\end{array}$ & $\begin{array}{c}0.988 \pm \\
0.002^{\mathrm{b}}\end{array}$ & $\begin{array}{c}6.37 \pm \\
0.03^{\text {DEa }}\end{array}$ & $\begin{array}{c}6.35 \pm \\
0.04^{\mathrm{CDEa}}\end{array}$ & $\begin{array}{l}6.03 \pm \\
0.02^{\mathrm{Bb}}\end{array}$ \\
\hline & Millet & $\begin{array}{l}7.48 \pm \\
0.02^{\mathrm{Ca}}\end{array}$ & $\begin{array}{c}25.26 \pm \\
1.26^{\mathrm{CDEFb}}\end{array}$ & $\begin{array}{c}0.300 \pm \\
0.007^{\mathrm{DEFGa}}\end{array}$ & $\begin{array}{c}0.986 \pm \\
0.000^{\mathrm{b}}\end{array}$ & $\begin{array}{c}6.56 \pm \\
0.05^{\mathrm{BCDa}}\end{array}$ & $\begin{array}{l}6.12 \pm \\
0.03^{\mathrm{Fb}}\end{array}$ & $\begin{array}{l}5.71 \pm \\
0.01^{\mathrm{EFc}}\end{array}$ \\
\hline & Quinoa & $\begin{array}{c}11.35 \pm \\
0.06^{\mathrm{Aa}}\end{array}$ & $\begin{array}{l}40.16 \pm \\
2.17^{\mathrm{BCb}}\end{array}$ & $\begin{array}{l}0.503 \pm \\
0.000^{\mathrm{Aa}}\end{array}$ & $\begin{array}{c}0.986 \pm \\
0.004^{\mathrm{b}}\end{array}$ & $\begin{array}{c}6.29 \pm \\
0.09^{\mathrm{Ea}}\end{array}$ & $\begin{array}{c}6.40 \pm \\
0.09^{\text {BCDEa }}\end{array}$ & $\begin{array}{l}6.30 \pm \\
0.00^{\text {Aa }}\end{array}$ \\
\hline \multirow{7}{*}{ Nuts } & Almond & $\begin{array}{c}2.41 \pm \\
0.03^{\mathrm{EFGa}}\end{array}$ & $\begin{array}{c}31.47 \pm \\
5.70^{\mathrm{CDEFa}}\end{array}$ & $\begin{array}{c}0.343 \pm \\
0.033^{\mathrm{CDEFa}}\end{array}$ & $\begin{array}{c}0.977 \pm \\
0.011^{\mathrm{b}}\end{array}$ & $\begin{array}{c}6.37 \pm \\
0.01^{\mathrm{DEa}}\end{array}$ & $\begin{array}{c}6.47 \pm \\
0.04^{\mathrm{ABCDa}}\end{array}$ & $\begin{array}{l}5.47 \pm \\
0.01^{\mathrm{Gb}}\end{array}$ \\
\hline & Cashew & $\begin{array}{l}3.23 \pm \\
0.38^{\mathrm{EFa}}\end{array}$ & $\begin{array}{l}39.56 \pm \\
2.78^{\mathrm{BCDb}}\end{array}$ & $\begin{array}{c}0.435 \pm \\
0.007^{\mathrm{ABa}}\end{array}$ & $\begin{array}{c}0.980 \pm \\
0.002^{\mathrm{b}}\end{array}$ & $\begin{array}{c}6.46 \pm \\
0.05^{\mathrm{CDEa}}\end{array}$ & $\begin{array}{c}6.51 \pm \\
0.01^{\mathrm{ABCa}}\end{array}$ & $\begin{array}{l}5.66 \pm \\
0.02^{\mathrm{Fb}}\end{array}$ \\
\hline & Hazelnut & $\begin{array}{l}2.99 \pm \\
0.07^{\mathrm{EFa}}\end{array}$ & $\begin{array}{c}28.84 \pm \\
0.39^{\mathrm{CDEFb}}\end{array}$ & $\begin{array}{c}0.416 \pm \\
0.009^{\mathrm{BCa}}\end{array}$ & $\begin{array}{c}0.984 \pm \\
0.003^{\mathrm{b}}\end{array}$ & $\begin{array}{c}6.42 \pm \\
0.02^{\mathrm{DEb}}\end{array}$ & $\begin{array}{c}6.57 \pm \\
0.04 \mathrm{~A}^{\mathrm{Ba}}\end{array}$ & $\begin{array}{c}5.83 \pm \\
0.01^{\mathrm{CDEc}}\end{array}$ \\
\hline & Peanut & $\begin{array}{l}1.13 \pm \\
0.13^{\mathrm{Ga}}\end{array}$ & $\begin{array}{c}25.33 \pm \\
2.51^{\mathrm{CDEFb}}\end{array}$ & $\begin{array}{l}0.256 \pm \\
0.004^{\mathrm{Ga}}\end{array}$ & $\begin{array}{c}0.986 \pm \\
0.003^{\mathrm{b}}\end{array}$ & $\begin{array}{l}6.74 \pm \\
0.01^{\mathrm{Ba}}\end{array}$ & $\begin{array}{l}6.64 \pm \\
0.03^{\mathrm{Aa}}\end{array}$ & $\begin{array}{l}6.30 \pm \\
0.02^{\mathrm{Ab}}\end{array}$ \\
\hline & Pecan & $\begin{array}{c}2.38 \pm \\
0.12^{\mathrm{EFGa}}\end{array}$ & $\begin{array}{c}16.66 \pm \\
2.66^{\mathrm{Fb}}\end{array}$ & $\begin{array}{c}0.382 \pm \\
0.024^{\mathrm{BCa}}\end{array}$ & $\begin{array}{c}0.983 \pm \\
0.004^{\mathrm{b}}\end{array}$ & $\begin{array}{c}6.27 \pm \\
0.03^{\mathrm{Eb}}\end{array}$ & $\begin{array}{c}6.49 \pm \\
0.02^{\mathrm{ABCa}}\end{array}$ & $\begin{array}{c}5.87 \pm \\
0.01^{\mathrm{CDc}}\end{array}$ \\
\hline & Pili nut & $\begin{array}{l}3.14 \pm \\
0.08^{\mathrm{EFa}}\end{array}$ & $\begin{array}{c}25.99 \pm \\
0.41^{\mathrm{CDEFb}}\end{array}$ & $\begin{array}{l}0.507 \pm \\
0.027^{\mathrm{Aa}}\end{array}$ & $\begin{array}{c}0.985 \pm \\
0.004^{\mathrm{b}}\end{array}$ & $\begin{array}{c}6.41 \pm \\
0.04^{\mathrm{DEa}}\end{array}$ & $\begin{array}{c}6.52 \pm \\
0.02^{\mathrm{ABCa}}\end{array}$ & $\begin{array}{l}5.71 \pm \\
0.02^{\mathrm{EFb}}\end{array}$ \\
\hline & Walnut & $\begin{array}{l}2.04 \pm \\
0.14^{\mathrm{FGa}}\end{array}$ & $\begin{array}{l}23.58 \pm \\
0.18^{\text {DEFb }}\end{array}$ & $\begin{array}{c}0.352 \pm \\
0.004^{\mathrm{CDEa}}\end{array}$ & $\begin{array}{c}0.985 \pm \\
0.000^{\mathrm{b}}\end{array}$ & $\begin{array}{c}6.41 \pm \\
0.01^{\mathrm{DEb}}\end{array}$ & $\begin{array}{c}6.58 \pm \\
0.00^{\mathrm{ABa}}\end{array}$ & $\begin{array}{l}5.66 \pm \\
0.03^{\mathrm{Fc}}\end{array}$ \\
\hline \multirow{4}{*}{ Seeds } & Flax & $\begin{array}{c}5.35 \pm \\
0.06^{\mathrm{Da}}\end{array}$ & $\begin{array}{c}69.48 \pm \\
3.33^{\mathrm{Ab}}\end{array}$ & $\begin{array}{c}0.276 \pm \\
0.001^{\mathrm{FGa}}\end{array}$ & $\begin{array}{c}0.977 \pm \\
0.000^{\mathrm{b}}\end{array}$ & $\begin{array}{l}5.88 \pm \\
0.05^{\mathrm{Fa}}\end{array}$ & $\begin{array}{l}5.85 \pm \\
0.02^{\mathrm{Ga}}\end{array}$ & $\begin{array}{c}5.94 \pm \\
0.05^{\mathrm{BCa}}\end{array}$ \\
\hline & Hemp & $\begin{array}{l}5.41 \pm \\
0.04^{\mathrm{Da}}\end{array}$ & $\begin{array}{l}54.30 \pm \\
0.68^{\mathrm{ABb}}\end{array}$ & $\begin{array}{c}0.291 \pm \\
0.000^{\mathrm{DEFGa}}\end{array}$ & $\begin{array}{c}0.999 \pm \\
0.001^{\mathrm{b}}\end{array}$ & $\begin{array}{l}7.20 \pm \\
0.04^{\mathrm{Aa}}\end{array}$ & $\begin{array}{l}6.64 \pm \\
0.03^{\mathrm{Ab}}\end{array}$ & $\mathrm{ND}^{\mathrm{b}}$ \\
\hline & Pumpkin & $\begin{array}{l}3.46 \pm \\
0.58^{\mathrm{Ea}}\end{array}$ & $\begin{array}{l}36.97 \pm \\
3.77^{\mathrm{CDEb}}\end{array}$ & $\begin{array}{c}0.284 \pm \\
0.001^{\mathrm{EFGa}}\end{array}$ & $\begin{array}{c}0.979 \pm \\
0.002^{\mathrm{b}}\end{array}$ & $\begin{array}{c}6.70 \pm \\
0.05^{\mathrm{BCa}}\end{array}$ & $\begin{array}{c}6.48 \pm \\
0.02^{\mathrm{ABCb}}\end{array}$ & $\begin{array}{l}4.68 \pm \\
0.02^{\mathrm{Hc}}\end{array}$ \\
\hline & Sunflower & $\begin{array}{l}3.65 \pm \\
0.11^{\mathrm{Ea}}\end{array}$ & $\begin{array}{c}29.42 \pm \\
5.08^{\mathrm{CDEFa}}\end{array}$ & $\begin{array}{l}0.264 \pm \\
0.001^{\mathrm{Ga}}\end{array}$ & $\begin{array}{c}0.986 \pm \\
0.000^{\mathrm{b}}\end{array}$ & $\begin{array}{c}6.54 \pm \\
0.04^{\mathrm{BCDa}}\end{array}$ & $\begin{array}{c}6.24 \pm \\
0.01^{\mathrm{EFb}}\end{array}$ & $\begin{array}{c}5.82 \pm \\
0.05^{\mathrm{CDEc}}\end{array}$ \\
\hline
\end{tabular}

aSoaking solution $\mathrm{pH}$ was measured after the completion of the $24-\mathrm{hr}$ soak. The initial $\mathrm{pH}$ of the water used for soaking was 6.44. ${ }^{b}$ Not determined.

cell density on the growth of Salmonella during soaking of different grains, nuts, and seeds.

\section{RESULTS AND DISCUSSION}

Moisture content, water activity, and $\mathrm{pH}$ values for the 15 grains, nuts, and seeds evaluated in this study are shown in Table 2. The initial moisture content for each product category ranged from 1.13 to $3.23 \%$ for nuts, 3.46 to $5.41 \%$ for seeds, and 7.48 to $11.35 \%$ for grains. Prior to soaking, moisture content was correlated with water activity for nuts $\left(P\right.$-value $\left.=0.0158 ; \mathrm{R}^{2}=0.769\right)$ and grains $(P$-value $\left.<0.0001 ; \mathrm{R}^{2}=0.649\right)$, but not for seeds $(P$-value $=0.3176$; 
$\left.\mathrm{R}^{2}=0.165\right)$. Initial water activities had a similar range across all product categories, from a low of 0.256 (peanut) to a high of 0.507 (pili nut). As expected, the 24-h soak led to significant increases in moisture content and water activity of all products. Flax seed absorbed the most water, from an initial moisture content of $5.35 \%$ to a final moisture content of $69.48 \%$. Hemp seed absorbed the next highest amount of water, increasing from 5.41 to $54.30 \%$. Quinoa and cashew achieved final moisture contents of approximately $40 \%$. Brown rice and pecans absorbed the least amount of water, increasing by 13.43 and $14.28 \%$, respectively. All products reached a water activity of at least 0.977 (almond and flax seed) after the 24-h soaking period, with no significant difference among the soaked products.

All of the grains, nuts, and seeds used in this study are considered to be low-moisture and low-acid products prior to soaking. The initial $\mathrm{pH}$ of each product is shown in Table 2. With the exception of flax seed ( $\mathrm{pH}$ 5.88), all of the unsoaked products fell within the narrow $\mathrm{pH}$ range of 6.27 to 6.74. Soaking did not have a significant impact on the $\mathrm{pH}$ of most grains, nuts, and seeds. However, soaking did lead to a statistically significant increase in the $\mathrm{pH}$ of walnuts (6.41 to 6.58 ) and quinoa (6.29 to 6.40) and a significant decrease in the $\mathrm{pH}$ of hemp seeds (7.20 to 6.64), pumpkin seeds (6.70 to 6.48 ), and sunflower seeds (6.54 to 6.24). Soaking solutions of peanut and quinoa maintained $\mathrm{pH}$ (6.30) throughout the 24 -h soaking periods, whereas the $\mathrm{pH}$ of the solution of all other products was significantly decreased at the end of the 24-h soak (the $\mathrm{pH}$ of the hemp seed solution was not measured). Soaking of buckwheat and flax seed led to modest $\mathrm{pH}$ decreases, to achieve final solution $\mathrm{pH}$ values of 6.03 and 5.94, respectively. The $\mathrm{pH}$ of soaking solution for the majority of products ranged from 5.47 to 5.87. The soaking solution of pumpkin seeds was drastically reduced to a final value of 4.68 after the 24 -h period.

The $\mathrm{pH}$ of the soaking solution is influenced by the hydration of components from the grains, nuts, and seeds along with their intrinsic enzymatic processes as they are rehydrated. The metabolism and reproduction of the native microbiota of each product type is likely the major contributor to changes in the $\mathrm{pH}$ of the soaking solution. Changes in the natural microbiota of the grains, nuts, and seeds before and after soaking are shown in Fig. 1A. The initial concentration of mesophilic bacteria on these lowmoisture products was fairly low, with average aerobic plate counts ranging from 1.40 (hazelnut) to 3.83 (sunflower seed) $\log \mathrm{CFU} / \mathrm{g}$; however, the cell density varied substantially between replicates, particularly for sunflower seed (1.48 to $6.34 \log \mathrm{CFU} / \mathrm{g}$ ) and cashew (1.30 to $4.48 \log \mathrm{CFU} / \mathrm{g}$ ) samples. Minimally processed, low-moisture products typically have lower aerobic plate counts; however, the variability can be significant, even within a product lot. Aerobic plate counts and their variability for similar products have been reported in previous reports $(1,4,6,23)$. Ambient soaking in water for $24 \mathrm{~h}$ led to large and significant increases in microbial populations on all products. All products supported the growth of $>3.00 \mathrm{log} \mathrm{CFU} / \mathrm{g}$ of bacteria, with brown rice, buckwheat, cashew, hazelnut, and peanut supporting increases of $>5 \log \mathrm{CFU} / \mathrm{g}$ within $24 \mathrm{~h}$ (Fig. 1C). Final cell densities were comparable to those previously reported for soaked pumpkin, sunflower, and chia seeds (14).

All of the products were inoculated and dried in a similar manner; however, there were small, but statistically significant, differences in the survival of the Salmonella

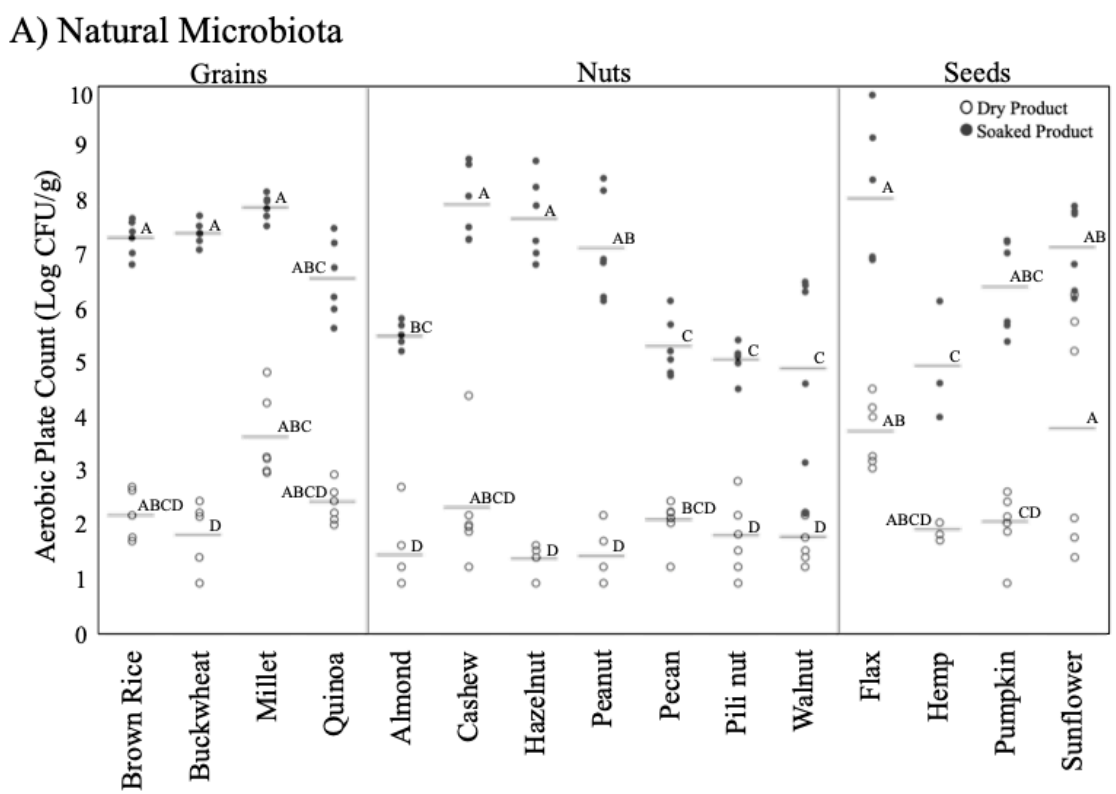




\section{B) Salmonella}

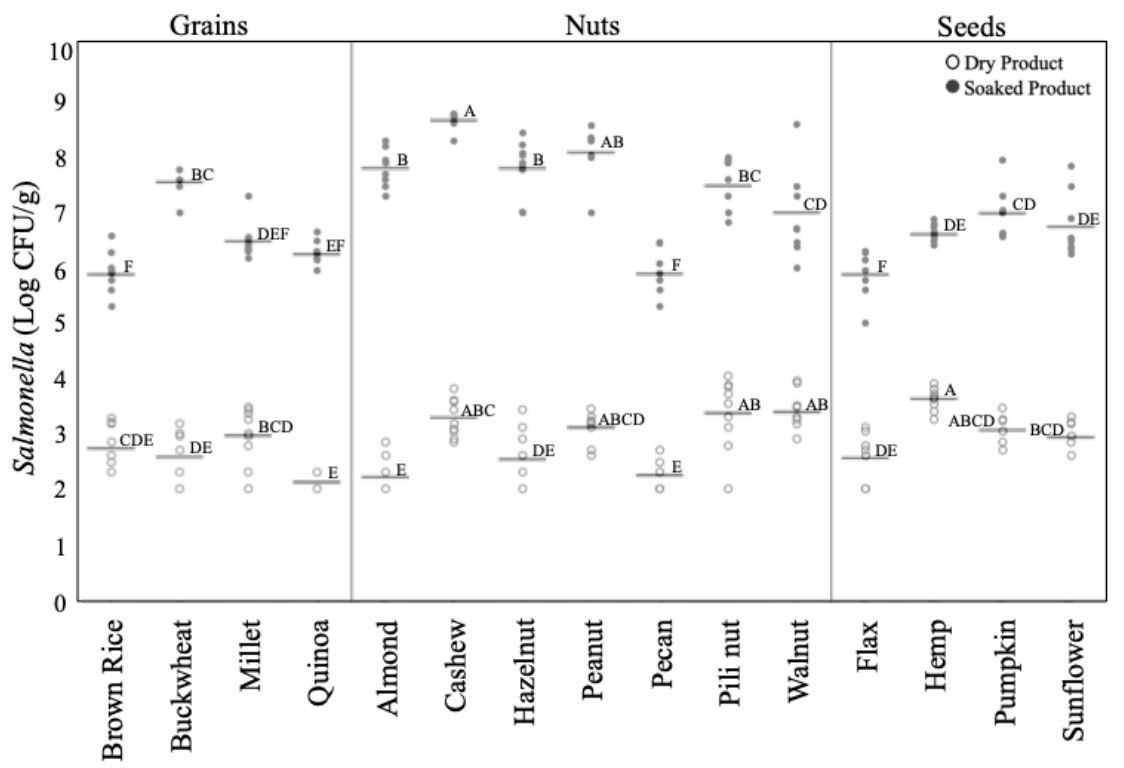

C) Growth

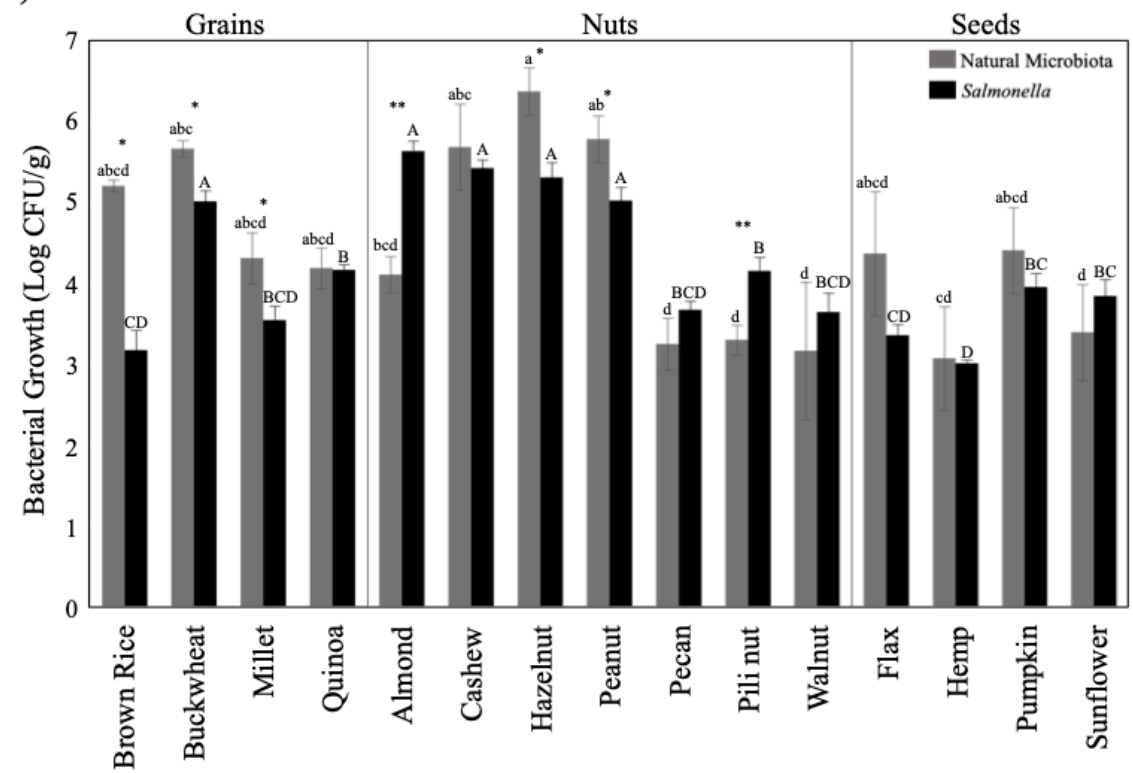

FIGURE 1. Natural microbiota (A) and Salmonella (B) cell density on grains, nuts, and seeds before (open circle) and after (closed circle) soaking. Growth (Log CFU/g) of natural microbiota and Salmonella after soaking (C). The soaking process consisted of a 24 -hrs hold in water at ambient temperature $\left(22 \pm 3^{\circ} \mathrm{C}\right)$. Natural microbiota cell densities for individual samples are represented as a circle with the mean indicated by a horizontal line $(n=6)$. Salmonella cell densities presented in an identical manner $(n=9)$. Bar height represents the mean \pm standard error $(n=9)$. At each timepoint, means with different letters are significantly different $(P<0.05)$. ${ }^{*}$ indicates significantly more growth of the natural microbiota at the end of the soaking period when compared to Salmonella $(P<0.05)$. ${ }^{* *}$ indicates significantly more growth of Salmonella at the end of the soaking period when compared to the natural microbiota $(P<0.05)$. 
inoculum on these dried products (Fig. 1B). Salmonella levels averaged between 2.10 (quinoa) and 3.61 (hemp) $\log \mathrm{CFU} / \mathrm{g}$ on the raw products prior to soaking. Salmonella inoculum levels were significantly higher on hemp, walnuts, and pili nuts and significantly lower on almonds, pecans, and quinoa. Initial pH (positively correlated; $P$-value $<0.0001$ ) and moisture content (negatively correlated; $P$-value $=0.0022$ ) were statistically significant parameters associated with the stability of the Salmonella inoculum on the grains, nuts, and seeds. The small reduction of the Salmonella inoculum during the drying phase was expected and has been reported in numerous previous studies of low-moisture foods (e.g., 2, 13, $15,22)$.

The primary purpose of this study was to quantify the potential for Salmonella to grow on grains, nuts, and seeds during the soaking process (ambient temperature, $24 \mathrm{~h}$ ) used for creating "sprouted" products. The growth of Salmonella on various commodities commonly "sprouted" is shown in Fig. $1 B$ and 1 C. All 15 of these commodities supported significant growth of Salmonella (>3.00 log CFU/g) within the 24 -h soaking period. Salmonella populations increased by $>5.00 \log \mathrm{CFU} / \mathrm{g}$ during the soaking of almonds, cashews, hazelnuts, peanut, and buckwheat. Significantly less growth (3- to 4-log CFU/g increase) was measured in hemp, brown rice, and flax. The growth of Salmonella during soaking of pumpkin seeds (3.95 log CFU/g) and sunflower seeds (3.84 $\log \mathrm{CFU} / \mathrm{g}$ ) is very similar to that seen in the previous study by Keller et al. (14). For the seeds, population increases in the natural microbiota and Salmonella were similar. Interestingly, Salmonella had significantly more growth during the soaking period than did the natural microbiota in two nuts (almond and pili) and significantly less growth in three of the grains (brown rice, buckwheat, millet) and two nuts (hazelnut and peanut). Salmonella cell density after the 24 -h soaking is likely influenced by the rate of hydration and the release of nutrients into solution. These, along with many other factors (temperature, $\mathrm{pH}$, macronutrient profile, mineral content, competing natural microbiota, etc.), will influence the lag time and the growth rate of Salmonella. Keller et al. (14) reported average lag times of $3.45 \mathrm{~h}$ (sunflower) to $6.68 \mathrm{~h}$ (chia) during soaking at $25^{\circ} \mathrm{C}$; however, these times were highly variable between replicates (standard deviations averaging $2 \mathrm{~h}$ ). Shortening the soaking time to $<3 \mathrm{~h}$ to mitigate the potential growth of Salmonella is not a viable option because many of these commodities would not be fully hydrated in this time frame.

The overall goal of the soaking step is to hydrate the grains, nuts, and seeds; however, this hydration also stimulates previously dormant bacterial cells into rapid proliferation. Due to the market demand for "sprouted" ingredients, it is important to identify and verify practical measures that would prevent the growth of pathogens during the soaking step. The potential for grains, nuts, and seeds to be contaminated with low levels of Salmonella or other foodborne pathogens is a significant risk; however, the risk for foodborne illness increases significantly if processing steps would support the proliferation of these pathogens. Almonds were selected as the target matrix due to their ability to support the most growth of Salmonella during soaking as well as for their high utilization in commercially available "sprouted" products. Through conversations with industry partners, the inclusion of salt in the soaking process and refrigeration were determined to be the most cost-effective and easily implementable options for modifying current procedures. High salt concentrations ( $>10 \%$ ) prevented the growth of Salmonella throughout the 24-h soaking of almonds under ambient conditions (Fig. 2). At higher salt concentrations (20\%), there was a significant inactivation (1.44-log CFU/g reduction) of Salmonella during soaking. Low-salt concentration (1.5\%) had no impact on the growth of Salmonella during soaking. Refrigeration $\left(<7^{\circ} \mathrm{C}\right)$ was also effective at preventing the growth of Salmonella on almonds within the 24-h soaking period. Whereas Salmonella is capable of growth at $7^{\circ} \mathrm{C}$, the growth rate is substantially slower and did not result in a measurable increase in cell density within the $24-\mathrm{h}$ soaking period. Processors relying on refrigeration must take care to confirm that refrigeration conditions are $<4^{\circ} \mathrm{C}$ and/or limit the soaking time at lower temperatures to prevent Salmonella growth. Investigations surrounding the 2015 Salmonella Paratyphi B outbreak linked to "sprouted" nut butters reported that the company conducted their soaking process under refrigeration but they did not apply a validated kill step (12). This situation demonstrates that refrigerated soaking may be an important control to prevent the growth of Salmonella; however, this approach was insufficient to eliminate risk associated with contaminated starting ingredients. Had their "sprouting" process occurred at ambient temperature without a subsequent kill step, the outbreak would likely have led to significantly more illnesses.

\section{CONCLUSIONS/RECOMMENDATIONS}

The use of typical soaking processes in the production of "sprouted" grains, nuts, and seeds at ambient temperature poses a significant risk due to the ability of Salmonella to grow rapidly in all 15 of the commodities tested. Although many companies further process "sprouted" ingredients, most use low-temperature dehydration to maintain a "raw" label. Dehydration, or other processing steps, could be optimized and validated to achieve a significant pathogen reduction; however, the current study demonstrates that the soaking stage of the "sprouting" process could lead to an increase in Salmonella of $>5 \log$ CFU/g. Therefore, the standard 5-log reduction typically targeted in process validation studies would be inadequate to achieve food safety goals in these processing systems. Potential growth of pathogens in a processing facility also creates a number of challenges for sanitation and other prerequisite programs that provide 


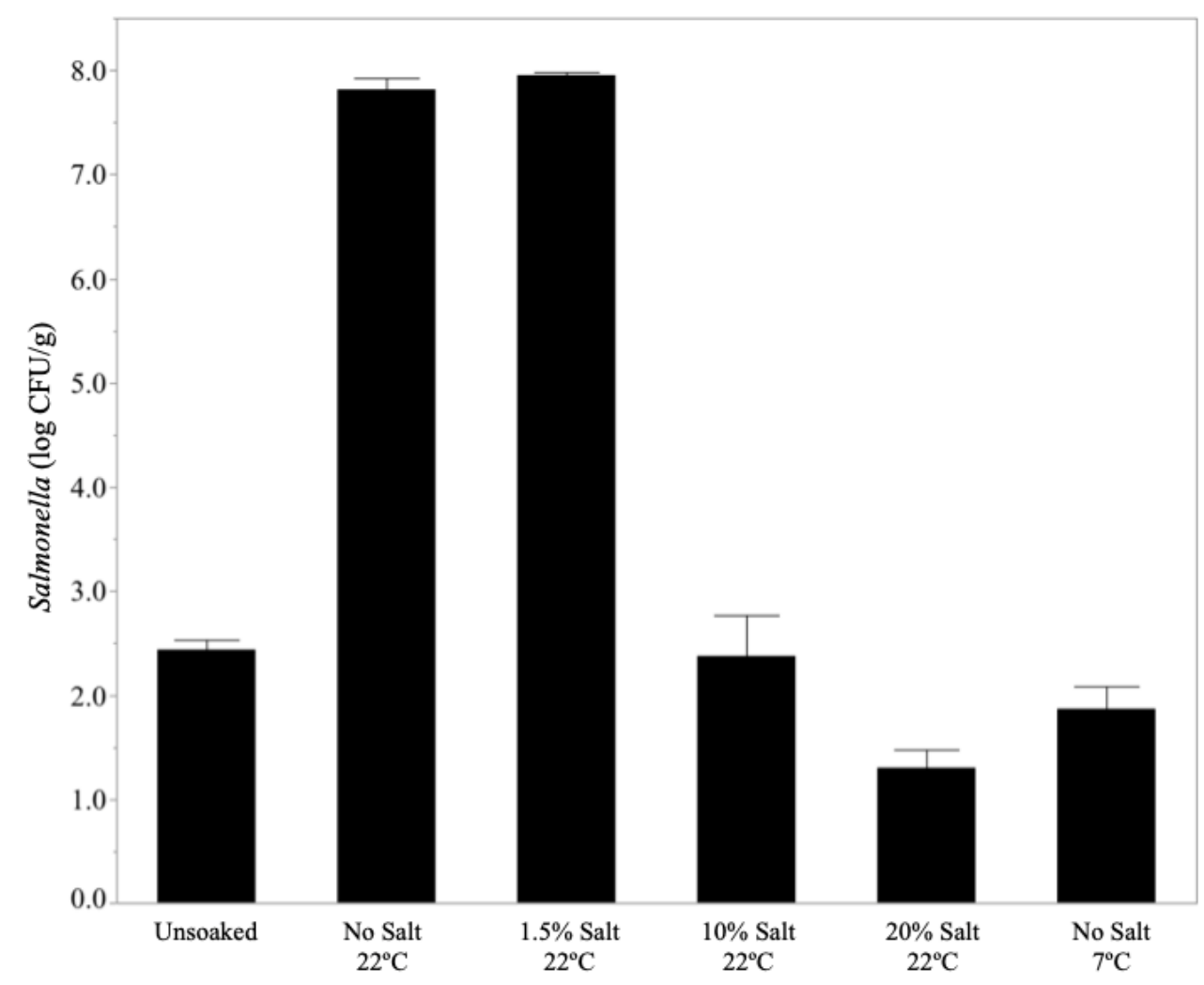

Almond Soaking Conditions

FIGURE 2. Impact of salt concentration and temperature on the cell density of Salmonella following a 24-hr soak of almonds in water. Bar height represents the mean \pm standard error ( $n=18$ unsoaked (dry product); $n=9$ no salt $/ 22^{\circ} \mathrm{C}, \mathrm{n}=3$ remaining treatments).

foundational food safety management within the processing environment. A mitigation strategy during the soaking stage must be implemented to prevent pathogen growth. This study demonstrates that high salt concentration $(>10 \%)$ or refrigeration $\left(<7^{\circ} \mathrm{C}\right)$ could be used as cost-effective strategies to reduce or prevent the growth of Salmonella during soaking.

\section{ACKNOWLEDGMENTS}

The authors thank various regional food entrepreneurs and processors for sharing information related to their processing practices and for providing product used in this study. The authors thank Linda Harris (University of California-Davis), Michelle Danyluk (University of Florida), Larry Beuchat (University of Georgia), Ahmed Yousef (The Ohio State University), and Karim Morey, Christianne Biggs, and Hillary Booth (Oregon State Public Health Labs) for providing Salmonella strains used in this study. We also acknowledge Rebecca Bland (Oregon State University) for her assistance with laboratory work and Jared Johnson (Oregon State University) for his editorial review of the manuscript.

\section{REFERENCES}

1. Bansal, A., T. M. Jones, S. J. Abd, M. D. Danyluk, and L. J. Harris. 2010. Mostprobable-number determination of Salmonella levels in naturally contaminated raw almonds using two sample preparation methods. J. Food Prot. 73:1986-1992.

2. Blessington, T., E. J. Mitcham, and L. J. Harris. 2012. Survival of Salmonella enterica, Escherichia coli O157:H7, and Listeria monocytogenes on inoculated walnut kernels during storage. J. Food Prot. 75:245-254.
3. Brar, P. K., L. K. Strawn, and M. D. Danyluk. 2016. Prevalence, level, and types of Salmonella isolated from North American in-shell pecans over four harvest years. J. Food Prot. 79:352-360.

4. Danyluk, M. D., T. M. Jones, S. J. Abd F. Schlitt-Dittrich, M. Jacobs, and L. J. Harris. 2007. Prevalence and amounts of Salmonella found on raw California almonds. J. Food Prot. 70:820-827.
5. Dykes, L., and L. W. Rooney. 2007. Phenolic compounds in cereal grains and their health benefits. Cereal Foods World 52:105-111.

6. Eglezos, S., B. Huang, and E. Stuttard. 2008. A survey of the bacteriological quality of preroasted peanut, almond, cashew, hazelnut, and Brazil nut kernels received into three Australian nut-processing facilities over a period of 3 years. J. Food Prot. 71:402-404. 
7. Gabriel, A. A., M. C. Berja, A. M. P. Estrada, G. A. A. Lopez, J. G. B. Nery, and E. J. B. Villaflor. 2007. Microbiology of retail mung bean sprouts vended in public markets of National Capital Region, Philippines. Food Control 18:1307-1313.

8. Grand View Research. 2017. Healthy snack market analysis, by product (cereal \& granola bars, nuts \& seeds snacks, meat snacks, dried fruit snacks, trail mix snacks), by region, and segment forecasts 2014-2025. Available at: https://www.grandviewresearch.com/ press- release/global-healthy-snack-market. Accessed July 7, 2020.

9. Harris, L. J., and S. Yada. 2018. Outbreaks of foodborne illness associated with the consumption of tree nut, legume, and seed pastes [Tables and references]. Available at: http://ucfoodsafety.ucdavis.edu/ files/277881.pdf. Accessed May 6, 2019.

10. Harris, L., S. Yada, L. Beuchat, and M. Danyluk. 2018. Outbreaks of foodborne illness associated with the consumption of tree nuts, peanuts, and sesame seeds (version 2) [Table and references]. Available at: http://ucfoodsafety.ucdavis.edu/ files/169530.pdf. Accessed May 6, 2019.

11. Harvey, R. R., K. E. Heiman Marshall, L. Burnworth, M. Hamel, J. Tataryn, J. Cutler, K. Meghnath, A. Wellman, K. Irvin, L. Isaac, K. Chau, A. Locas, J. Kohl, P. A. Huth, D. Nicholas, E. Traphagen, K. Soto, L. Mank, K. Holmes-Talbot, M. Needham, A. Barnes, B. Adcock, L. Honish, L. Chui, M. Taylor, C. Gaulin, S. Bekal, B. Warshawsky, L. Hobbs, L. R. Tschetter, A. Surin, S. Lance, M. E. Wise, I. Williams, and L. Gieraltowski. 2017. International outbreak of multiple Salmonella serotype infections linked to sprouted chia seed powder-USA and Canada, 2013-2014. Epidemiol. Infect. 145:1535-1544.

12. Heiman Marshall, K. E., H. Booth, J. Harrang, K. Lamba, A. Folley, M. Ching-Lee, E. Hannapel, V. Greene, A. Classon, L. Whitlock, L. Shade, S. Viazis, T. Nguyen, and K. P. Neil. 2018. New product, old problem(s): multistate outbreak of Salmonella Paratyphi B variant $\mathrm{L}(+)$ tartrate $(+)$ infections linked to raw sprouted nut butters, October 2015. Epidemiol. Infect. https://doi. org/10.1017/S0950268818002716.

13. Hobbs, S. H. 2005. Attitudes, practices, and beliefs of individuals consuming a raw foods diet. Explore J. Sci. Heal. 1:272-277.

14. Keller, S. E., N. M. Anderson, C. Wang, S. J. Burbick, I. M. Hildebrandt, L. J. Gonsalves, Q. J. Suehr, and S. M. S. Farakos. 2018. Survival of Salmonella during production of partially sprouted pumpkin, sunflower, and chia seeds dried for direct consumption. J. Food Prot. 81:520-527.

15. National Advisory Committee on Microbiological Criteria for Foods. 1999. Microbiological safety evaluations and recommendations on sprouted seeds. Int. J. Food Microbiol. 52:123-153.

16. Nkhata, S. G., E. Ayua, E. H. Kamau, and J. B. Shingiro. 2018. Fermentation and germination improve nutritional value of cereals and legumes through activation of endogenous enzymes. Food Sci. Nutr. $6: 2446-2458$.

17. Ros, E. 2010. Health benefits of nut consumption. Nutrients 2:652-682.

18. Saleh, A. S. M., Q. Zhang, J. Chen, and Q. Shen. 2013. Millet grains: nutritional quality, processing, and potential health benefits. Compr. Rev. Food Sci. Food Saf. 12:281-295.

19. Schmitt, N., G. Yu, R. Greve, and L. McIntyre. 2018. Outbreak of S. Weltevreden linked to fermented cashew nut cheese in Victoria, BC. Environ. Health Rev. 61:74-81.

20. Tamber, S., E. Swist, and D. Oudit. 2016 Physicochemical and bacteriological characteristics of organic sprouted chia and flax seed powders implicated in a foodborne salmonellosis outbreak. J. Food Prot. 79:703-709.
21. U.S. Food and Drug Administration. 2017. Draft guidance for industry: compliance with and recommendation for implementation of the standards for the growing, harvesting, packing, and holding of produce for human consumption for sprout operations. Available at: https://www.fda.gov/ downloads/Food/ GuidanceRegulation/ GuidanceDocumentsRegulatory Information/UCM537031.pdf. Accessed October 1, 2019.

22. Viswanathan, P., and R. Kaur. 2001. Prevalence and growth of pathogens on salad vegetables, fruits and sprouts. Int. J. Hyg. Environ. Health 203:205-213.

23. Vural, A., and M. E. Erkan. 2008. The research of microbiological quality in some edible nut kinds. J. Food Technol. 6:25-28.

24. Waje, C., S. Jun, Y. Lee, B. Kim, D. Han, C. Jo, and J. Kwon. 2009. Microbial quality assessment and pathogen inactivation by electron beam and gamma irradiation of commercial seed sprouts. Food Control 20:200-2004.

25. Yada, S., and L. J. Harris. 2018. Recalls of tree nuts and peanuts in the U.S., 2001 to present (version 2) [Table and references]. Available at: http://ucfoodsafety.ucdavis.edu/ files/43637.pdf. Accessed May 6, 2019.

26. Zhang, G., L. Hu, D. Melka, H. Wang, A. Laasri, E. W. Brown, E. Strain, M. Allard, V. K. Bunning, S. M. Musser, R. Johnson, S. M. S. Farakos, V. N. Scott, R. Pouillot, J. M. Van Doren, and T. S. Hammack. 2017. Prevalence of Salmonella in cashews, hazelnuts, macadamia nuts, pecans, pine nuts, and walnuts in the United States. J. Food Prot. 80:459-466. 